\title{
ФУНКЦІЮВАННЯ МОРФОЛОГІЧНИХ ОДИНИЦЬ ЯК ЕВФЕМІЗМІВ / ДИСФЕМІЗМІВ В АСПЕКТІ ГРАМАТИКИ ОЦІНКИ
}

У статті описано особливості функиіювання морфологічних одиниць як евфемізмів / дисфемізмів в аспекті граматики оцінки в сучасній украӥнській мові. Для аналізу обрано полібункиійні засоби, які репрезентують механізми з полярними аксіологічними смистами, що дає змогу змінювати аксіологічний вектор уживання мовного засобу в конкретній ситуації спілкування. У результаті дослідження засвідчено використання форм середнього роду як евфемізмів і числових форм (удаваної пошанності, однини агресивної) як дисфемізмів у процесі моделювання оцінних значень.

Ключові слова: морфологічна одиниия, оцінка, евфемізм, дисфемізм, граматика оцінки.

\section{Khaliman O. Functioning of Morphological Units as Euphemisms /} Dysphemisms in the Aspect of the Grammar of Estimation. Interest in modelling of secondary semantic meanings dates back to ancient times. Euphemisms and dysphemisms attract attention among other tropes based on the secondary nomination. Their study in the aspect of the expression of estimation is relevant in modern linguistics.

The purpose of this article is to characterise the features of functioning of morphological units as euphemisms / dysphemisms in the aspect of the grammar of estimation in modern Ukrainian language. This aim involves solving the following tasks: 1) to describe the specifics of the use of neuter gender forms as euphemisms in the process of modelling of estimation; 2) to highlight the features of the use of number forms as dysphemisms for the expression of axiological meanings.

Creation of euphemistic and dysphemic substitutes occurs at different language levels. Multifunctional means with polar axiological meanings were selected for the analysis that allows changing the axiological vector of using the language in a specific communicative situation. The study has shown the use of neuter gender forms as euphemisms and number forms (respectful plural, aggressive singular) as dysphemisms in the process of modelling of estimation in modern Ukrainian language.

Negative estimation of neuter gender forms is euphemized due to the existence of parallel neuter gender forms with a positive estimation in the linguistic consciousness of communicators. Positive estimation of grammatical ludisms is dysphemized (pretended respect, aggressive singular) due to a change in the communicative intention to use forms, the lack of grounds to express respect / intimization. 
Names, which emerge as a result of the figurative usage, indicate the versatility of the language sign and contribute to the development of the language system. The actualization of other morphological means in the process of tropes modelling in terms of linguoaxiology is going to be characterized eventually.

Key words: morphological unit, estimation, euphemism, dysphemism, the grammar of estimation.

\section{Вступ}

Креативне застосування мовної одиниці може зумовлювати семантичну двоплановість між іiі формою та змістом, унаслідок чого денотативний семантичний компонент доповнює конотативний. Стилістично маркована вторинна номінація є основою тропів - слів, уживаних у переносному значенні для характеристики певних денотатів, посилення образності мови, художньої виразності мовлення.

Цікавість до таких уживань сягає античних часів. Сутність свідомого відхилення під час використання мовних одиниць, як відзначав ще Квінтіліан, полягає в тому, що на їхній денотативний зміст накладаються елементи виразності, які виникли внаслідок мисленнєвих операцій тотожності, схожості, суміжності, контрасту і які є тим образним субелементом, що дає “прирощення” значення (Мацько, Сидоренко, \& Мацько, 2005: 327). Коріння тропеїчності мови (ії здатності до творення тропів) закладені в асиметрії плану змісту та плану вираження мовних одиниць.

Вивчення евфемії дослідники вважають актуальною лінгвістичною проблемою, адже останнім часом процеси утворення евфемізмів відбуваються надзвичайно інтенсивно. Зокрема, мовознавці констатували їхнє активне вживання в 3МI, суспільно значущих сферах мовленнєвої діяльності, що зумовлено передусім «уникненням соціального чи особистого табу, досягненням комунікативного комфорту всіма учасниками комунікації, наданням експліцитної чи імпліцитної позитивної оцінки, досягненням бажаного прагматичного впливу на реципієнта тощо» (Решетарова, 2010: 16). Є. Корнєлаєва виділяє чотири прагматичні функції евфемізмів: функції ввічливості, табуювання, вуалювання й етикету (Корнєлаєва, 2019: 73).

Менш дослідженими $є$ особливості функціювання дисфемізмів - одиниць із вульгарним, фамільярним, грубим відтінком, хоча їхє вживання не менш поширене в сучасному мовленні, що відзначається свободою вибору мовних засобів. Окремі публікації, навпаки, 
засвідчують посилене вживання дисфемізмів у мові сучасної публіцистики, що пояснюють також загальною тенденцією поширення критики опонентів у сучасному політичному житті й, відповідно, перевагою негативної оцінки в її відтворенні (Гнатківська: 2009).

Функціювання евфемізмів і дисфемізмів, пояснює Т. Абакова, зумовлене соціальною ситуацією спілкування. Чим більш офіційна ситуація спілкування, тим більше уваги звертає мовець на вибір мовних одиниць i, відповідно, більша ймовірність використання евфемізмів. Під час вільного спілкування, що не передбачає офіційності й високого рівня контролю над мовленням, можливе вживання дисфемізмів (Абакова, 2007).

Здатність виконувати оцінну функцію, як наголошує Л. Дейна, відображає потенціал тропів, оскільки висловлення власної думки про об’єкт у формі метафори, оксиморона, перифрази й т. ін. репрезентує авторську небайдужість до цього об'єкта, позитивно або негативно марковану цінність (Дейна, 2016). Використання евфемізмів і дисфемізмів теж пов'язане з категорією оцінки, зокрема як домінувальні функції сучасних медійних евфемізмів і дисфемізмів дослідники називають маніпулятивну й оцінну (Решетарова, 2010: 5). Цю думку підтримує і Ю. Полтавець, зауважуючи, що в евфемізмах і дисфемізмах як одиницях вторинної номінації яскраво проявляється людський чинник, адже вони мотивовані психологічно та соціально, є виявом оцінки адресантом певного явища (Полтавець, 2012: 225). Уживання евфемізмів спрямоване на попередження негативних емоцій, дисфемізмів - на їх провокування (Полтавець, 2012: 228).

Мета цієї розвідки - схарактеризувати особливості функціювання морфологічних одиниць як евфемізмів / дисфемізмів в аспекті граматики оцінки в сучасній українській мові. Зазначена мета передбачає розв'язання таких завдань: 1) описати специфіку вживання форм середнього роду як евфемізмів у процесі моделювання оцінних значень; 2) висвітлити особливості використання числових форм (удаваної пошанності, однини агресивної) як дисфемізмів для вираження аксіологічних смислів.

\section{Методи дослідження}

У роботі послідовно застосовано метод спостереження - для систематичного й цілеспрямованого сприйняття досліджуваного матеріалу з метою осмислення його властивостей; аналізу й синтезу - для 
ідентифікації та розрізнення типів досліджуваних одиниць і подання їх у системному комплексі, порівняння - для вияву спільних і специфічних ознак мовних одиниць; описовий метод як сукупність процедур інвентаризації, таксономії й інтерпретації мовних знаків на конкретному етапі розвитку мови. Застосування функційного методу передбачає дослідження мови в процесі функціювання, що зумовило використання контекстуально-інтерпретаційного, прагматичного аналізів для вияву специфіки оцінного характеру мовних засобів у конкретних контекстуальних умовах. Методи вибірки залучено для відбору фактичного матеріалу.

\section{Виклад основного матеріалу}

Серед засобів вираження аксіологічних смислів - морфологічні одиниці, комплексний аналіз яких формує морфологію оцінки як підрозділ граматики оцінки, у якій мовні засоби об'єднані як прагматично значущі за їхнью функційною (оцінною) спеціалізацією (Халіман, 2019).

Окремі граматичні засоби вираження оцінки функціюють як евфемізми - слова, що пом'якшують негативну інформацію, не викликають грубих, неприємних і неприйнятних уявлень та відчуттів. Це, зокрема, відбувається тоді, коли окрема граматична одиниця може брати участь у моделюванні механізмів і з позитивним, і з негативним значеннями. У цьому разі залежно від інтенцій мовця, конкретної ситуації спілкування і численних позамовних чинників оцінка, виражена одним і тим самим засобом, “ковзає” на відповідній шкалі від крайнього позитиву до крайнього негативу. Саме завдяки такій різнофункційності засобу й можливе деяке проміжне вживання між аксіологічними полюсами. 3 одного боку, моделюючи негативну оцінку, доповнюючись прийомами інтимізації, такий засіб функціює як евфемізм, тобто інтимізація евфемізує негатив: завдяки існуванню у свідомості комунікантів досвіду використання такої одиниці з позитивною оцінкою відповідне вживання з негативнооцінним змістом евфемізується. 3 другого боку, іронія, що супроводжує вживання позитивнооцінного засобу, не забезпечує різкої зміни його на негативнооцінний, а лише додає “легкого” негативно-іронічного відтінку через функціювання засобу як евфемізму.

У попередніх публікація авторкою цієї наукової розвідки було детально описано фунціювання граматичних форм середнього роду як 
засобів моделювання аксіологічних смислів. Під час цілеспрямованої заміни словоформ чоловічого чи жіночого родів формами середнього роду виникає граматична ігрема: суперечність між граматичним значенням середнього роду й статтю позначуваної особи (чоловічою чи жіночою) зумовлює актуалізацію аксіологічних відтінків значення (Космеда, \& Халіман, 2013: 131). Позитивну оцінку формує зіставлення номінованої особи з дитиною, що моделює пестливу тональність мовлення, негативна оцінка з'являється внаслідок ігнорування статі дорослого / дорослої, що зумовлює їх приниження. Обидва типи моделювання оцінних смислів за участю граматичного значення середнього роду грунтуються на зіставленні дорослого - недорослого, що викликає позитивні асоціації або сприймається як недоречне, зокрема й негативне.

Наповнюючи дискурс іронією, мовець може змінювати аксіологічне спрямування висловлення, оскільки порівняння з дитиною в різних контекстах отримує протилежну оцінку: іронічна пестливість змінюється на зневажливість. Крім того, переносне вживання форм середнього роду - це інтимізований прийом, що його використовують для створення відповідного прагматичного ефекту - пом'якшення негативної оцінки через комунікативні табу іï вираження. Тому таке слововживання як прийом евфемізації мовці застосовують у процесі іронічного вираження негативу для зменшення категоричності, грубості, що може бути сприйнята співрозмовником як різко негативна оцінка, образа. У цьому разі негативнооцінні ігреми за участю граматичного значення середнього роду функціюють як евфемізовані одиниці, що забезпечує досвід використання мовцями відповідних моделей у позитивнооцінних функціях. Такий прийом реалізують форми різних частин мови: займенник воно, атрибутивні одиниці (прикметники, присвійні, указівні займенники), субстантивовані прикметники, дієслова, іменники (моделювання іменників-новотворів, зміна роду іменників на середній) (Халіман, 2019: 150-158).

Спостерігаємо використання як евфемізмів утворень на зразок дурко (замість дурний, дурень), тупко (замість тупий), сліпко (замість сліпий), страшко (замість страшний) і т. ін., порівн.: Я скільки тебе знаю, земляче, а не думав, що ти таке дурко... Башка закрутилася? (А. Кокотюха); Ну, погодься, Марія Василівна - дурко! Як з ії досвідом можна таке зробити! (з розм. мовл.); Ти не тупко, а емоціональна 
панночка. А иее дві великі різниці, як кажуть в Одесі (з коментарів на інтернет-форумі). Мовці самі пояснюють необхідність використання таких засобів через вікові, статусні та ін. причини заборони виражати негативну оцінку у відповідних комунікативних ситуаціях. Табу у вираженні негативу зумовило потребу створення засобу-евфемізму для пом'якшення негативної оцінки завдяки вияву інтимізованого ставлення, вираженню пестливого відтінку, типового в ставленні до дитини.

Виникла потреба фіксувати в лінгвістичній літературі подібні утворення й указувати на їхню прагматичну особливість, що не лише допоможе в спілкуванні носіям мови, а також важливо в міжкультурній комунікації (порівн. питання, що його обговорювали на інтернет-форумі /у перекладі укр./: Народе, потрібна допомога! Іноземия жартома назвали дуркО, а він тепер запитує, що ие значить. Як йому пояснити?). Комунікативні табу потребують усебічного опису й систематизації, очевидно, і у формі відповідного словника.

Іноді спостерігаємо високий ступінь евфемізації: негативна оцінка взагалі відходить на другий план, забезпечуючи сприйняття позитиву, симпатії, грайливості, напр.: Все одно я тебе кохаю. I у мене від тебе зносить дах. Я постійно про тебе думаю, я постійно хочу бути з тобою. Як добре, що ти у мене є, дурко моє. Я завжди буду з тобою (з інтернет-ресурсів).

Мовці часто використовують досліджувані форми для самохарактеристики, що зручно для вираження самокритики й одночасно для зменшення негативу до самого себе, порівн.: Ну я й тупко! Як можна було все переплутати?! (з розм. мовл.).

Отже, у подібних прикладах форми середнього роду функціюють як евфемізми - слова, що пом'якшують негативну інформацію, не викликають грубих, неприємних і неприйнятних уявлень і відчуттів. Негативна оцінка форм середнього роду евфемізується завдяки існуванню в мовній свідомості комунікантів паралельних зменшенопестливих форм середнього роду з позитивною оцінкою та комунікативного досвіду їх уживання.

Спостерігаємо функціювання досліджуваних морфологічних засобів як дисфемізмів, що також грунтується на здатності мовних одиниць виражати полярні аксіологічні відтінки значення.

У зазначеному вище аспекті привертає увагу вживання форм множини пошанної / удаваної пошанності, що раніше було 
схарактеризовано авторкою цієї розвідки в аспекті лінгвоаксіології (Халіман, 2019: 186-195). Категорія пошанності $€$ способом вираження позитивної ввічливості та розкриває наміри мовця передати шанобливе або ж регламентоване етикетом увічливе ставлення до адресата мовлення і фіксується системою спеціалізованих звертань - ігрем за участю форм числа. Множинні форми закріплюють узвичаєну норму вираження пошанності, увічливості, позитивної оцінки й правила їі вживання, що може бути репрезентоване, зокрема, за допомогою займенника $\boldsymbol{B u}$.

Смисли удаваної пошанності пов'язані з таким уживанням займенника $B u$, що передбачає не вияв поваги, а формування відчуженості, концентрує увагу на “втраті” інтимізації, перехід на негативну ввічливість ${ }^{1}$. Зокрема, у певній ситуації з комунікативною, стилістичною метою спостерігаємо форму Ви замість $m u$, наприклад, під час сварки між близькими, рідними, порівн. (у перекладі укр.): Степан Полікарпович знову перейшов на «Ви». Це чомусь нагадувало проголошення війни (Генрі Лайон Олді).

Наявність у мовленні двох аксіологічно полярних моделей застосування займенника Ви зумовлена тим, що «Ви-форми виконують одночасно дві функції: указують на наявність значної горизонтальної та вертикальної (статусної) дистанції між учасниками спілкування й виражають більший ступінь поваги до адресата, ніж звертання на ти» (Шкіцька, 2012: 168). Недоречне вживання мовцем пошанної множини, зокрема щодо самого себе, породжує негативну оцінку. У цьому разі спостерігаємо іронічне перенесення ввічливого, позитивного ставлення, що забезпечує зміну аксіологічного маркування і демонструє вживання мовної одиниці як дисфемізму.

Мовець, як демонструють приклади, може використовувати множинні форми для показового вираження пошанності з метою маніпулятивного впливу на співрозмовника, порівн.: - Так що ж, панове, та ще й які панове! Що тепер пан перед вами! Ви, Грицьку, тепер пан! От хто пан! Що схочете в волості, те й зробите! Ви, Петре, тепер господар на все село, ніби князь! Тепер ви пани, а пани вже перевелись на Іиькову сучку, - підлешувався Берко до мужиків. - Та що ж, панове, чи згодитесь громадою оддати мені й свій шинк, і будете пускати людей

1 За теорією П. Браун і С. Левінсона (Brown, \& Levingson, 1987), реалізуючи стратегії негативної ввічливості, комунікант прагне мінімалізувати втручання в персональну сферу співрозмовника, зберегти дистанцію. 
в мої шинки? (І. Нечуй-Левицький). У цьому разі теж бачимо моделювання вдаваної пошанності, що, зокрема, підтверджує лексема підлещувався і пояснює причини моделювання відповідної тональності мовлення та демонструє дисфемізацію аксіологічної маркованості.

Так само займенник ти, уживаючись в апелятивній функції, крім звичної для нього функції інтимізації мовлення, може моделювати й протилежні смисли, фунціюючи як дисфемізм. Його використання в офіційній ситуації під час звертання до незнайомого або малознайомого, старшого за віком Ю. Щербініна розглядає як прояв мовленнєвої агресії («образливе спілкування, словесне вираження негативних емоцій, почуттів або намірів в образливій, грубій, неприйнятній у певній мовній ситуації формі» (Щербинина, 2004: 5)), що «веде до порушення гармонії спілкування, провокує заперечення, незадоволення, протест співрозмовника» (Щербинина, 2004: 162).

Перехід одного чи обох учасників діалогу з увічливого $B u$ до фамільярного ти (однина агресивна (Халіман, 2019: 200-204)) $€$ прагматичним засобом негативного емоційного впливу. Вона стає «свідченням відсутності поваги, проявом агресії, невихованості, особливо якщо йдеться про ситуації спілкування незнайомих дорослих або звертання начальника до підлеглого з метою підвищення свого соціального статусу й зниження статусу адресата» (Шкіцька, 2011: 401). Утім навмисне використання $m u$-звертання може слугувати й засобом вираження неповаги до співрозмовника, його негативної оцінки ( знайомих людей, де прономінатив другої особи однини функціює з емоційно-експресивним згрубілим (грубим) чи фамільярним, панібратським значенням) (Ожоган, 1997: 127)), напр.: Слухай, ти! Очкарик! Ти думаєщ, ти розумний? Так?.. Помиляєшся! Дурний ти, а не розумний (В. Нестайко); “Слухай, ти, пои, перестань робити провокаиіі...»- - вернувся депутат до бійия (з інтернет-мережі); Слухай, ти, шпана продажна, ти про мораль можеш говорити? Біжи до Порошенка свої срібняки отримувати (з інтернет-мережі; Степан Хмара політологу Палію). Недоречне застосування форм однини (займенник ти) дисфемізує мовлення і слугує засобом висловлення неповаги, негативної оцінки.

Отже, у наведених вище прикладах числові форми (наприклад, займенники $m u$ / Bu) функціюють як дисфемізми - слова з грубими 
відтінками значення. Позитивна оцінка граматичних ігрем дисфемізується через зміну комунікативного наміру вживання форм, відсутність підстав для вираження інтимізації $(\mathrm{mu})$ / пошанності $(\mathrm{Bu})$.

Використання засобів, здатних моделювати й позитивне, і негативне значення, може супроводжуватися непорозумінням, комунікативними девіаціями, оскільки аксіологічна маркованість може бути потрактована реципієнтом невідповідно до інтенцій адресанта, що залежить від комунікативного досвіду кожного з них. Тлумачення одиниць вторинної номінації «залежить від контексту спілкування і забезпечується здатністю людини асоціативно мислити. Щоб зрозуміти евфемістичний чи дисфемістичний замінник, у мовця мають виникнути правильні асоціації, які дадуть змогу співвіднести субститут з денотатом» (Полтавець, 2012: 228).

\section{Висновки}

Процеси евфемізації та дисфемізації - дві протилежні тенденції мовлення, що зумовлюють, з одного боку, пом'якшення, маскування негативної оцінки, а з другого, - огрублення висловлення, посилення негативу. Евфемізми забезпечують зменшення ступеня негативної ознаки (або ж зміну оцінного знака з негативного на позитивний), дисфемізми, навпаки, посилюють негатив. Уживання дисфемізмів може руйнувати систему загальноприйнятих норм і цінностей, оскільки з дисфемізацією пов'язане вираження неввічливості, недоречної категоричності, що й моделює пейоративну тональність.

Утворення евфемістичних і дисфемістичних замінників відбувається на різних рівнях мови. Під час моделювання окремих тропів спостерігаємо актуалізацію граматичних засобів, що супроводжується породженням оцінних відтінків значення. Це, зокрема, зафіксовано в процесі вживання поліфункційних засобів, що репрезентують механізми з полярними аксіологічними смислами. Аналіз засвідчив уживання форм середнього роду як евфемізмів та форм удаваної пошанності й однини агресивної як дисфемізмів, що пов'язано з особливостями конкретних комунікативних ситуацій.

Найменування, що виникають унаслідок перенесення значення, свідчать про багатогранність мовного знака й сприяють розвитку мовної системи. У перспективі плануємо схарактеризувати актуалізацію інших морфологічних засобів у процесі моделювання тропів в аспекті лінгвоаксіології. 


\section{ЛIТЕРАТУРА}

1. Абакова, Т. Н. (2007). Парадигматические отношения и семантико-прагматические особенности эвфемизмов и дисфемизмов современного английского языка (на материале текстов британской прессы). (Дис. ... канд. філол. наук). Саратов: Саратов. гос. акад. права. 2. Гнатківська, Р. (2009). До проблеми дисфемії в сучасній англомовній пресі. Вісн. Львів. ун-my, 16, 14-22. 3. Дейна, Л. В. Суб’єктивна та об’єктивна оцінка в українському щоденниковому дискурсі. (Дис. ... канд. філол. наук). Запоріжжя: Запоріз. держ. ун-т, 2016. 4. Корнєлаєва, Є. В. (2019). Лінгвістична природа евфемізмів. Наук. журн. Львів. держ. ун-ту безпеки життєдіяльності «Львів. філол. часопис», 5, 70-71. https://doi.org/10.32447/2663-340X-2019-5-12. 5. Космеда, Т. А., \& Халіман, О. В. (2013). Мовна гра в парадигмі інтерпретативної лінгвістики. Граматика оцінки. Граматична ігрема (теоретичне осмислення дискурсивної практики). Дрогобич: Коло. 6. Мацько, Л. І., Сидоренко, О. М., \& Мацько, О. М. (2005). Стилістика украйнської мови. Київ: Вища школа. 7. Ожоган, В. (1997). Займенникові слова у граматичній структурі сучасної украӥнської мови. Київ: НАН України. Ін-т укр. мови. 8. Полтавець, Ю. (2012). Основні підходи до вивчення евфемізмів і дисфемізмів. Гуманітарна освіта в технічних навчальних закладах, 24, 225-236. 9. Решетарова, I. В. (2010). Засоби евфемії в масмедійному дискурсі початку XXI століття. (Автореф. ... канд. філол. наук). Донецьк: ДНУ. 10. Халіман, О. В. (2019). Граматика оцінки: морфологічні категорії украӥнської мови. Харків: Майдан. 11. Шкіцька, І. Ю. (2011). Займенники «ти» - «Ви» в маніпулятивній стратегії позитиву. Актуальні проблеми слов'янської філології. Серія «Лінгвістика і літературознавство», XXIV (Ч. 1), 400-408. 12. Шкіцька, І. Ю. (2012). Маніпулятивна стратегія позитиву в українській мові. (Дис. ... докт. філол. наук). Київ: Ін-т мовознавства ім. О. О. Потебні НАН України, 2012. 13. Щербинина, Ю. В. (2004). Русский язык: Речевая агрессия и пути ее преодоления. Москва: Флинта: Наука. 14. Brown, P., \& Levingson, S. (1987). Politeness: Some Universals in Language. Cambridge: Cambridge Univ. Press.

\section{REFERENCES}

1. Abakova, T. N. (2007). Paradigmaticheskie otnosheniya i semantiko-pragmaticheskie osobennosti e'vfemizmov i disfemizmov sovremennogo anglijskogo yazyka (na materiale tekstov britanskoj pressy) [Paradigmatic relations and semantic-pragmatic features of euphemisms and dysphemisms of modern English (based on the texts of the British press)]. Candidate's thesis. Saratov: Saratov. gos. akad. prava [in Russian]. 2. Hnatkivska, R. (2009). Do problemy dysfemii v suchasnii anhlomovnii presi [To the problem of dysphemia in the modern English-language press]. Visn. Lviv. un-tu - Bulletin of Lviv University, 16, 14-22 [in Ukrainian]. 3. Deina, L. V. Sub'iektyvna ta obiektyvna otsinka v ukrainskomu shchodennykovomu dyskursi [Subjective and objective estimation in Ukrainian daily discourse]. Candidate's thesis. Zaporizhzhia: Zaporiz. derzh. un-t, 2016 [in Ukrainian]. 4. Kornielaieva, Ie. V. (2019). Linhvistychna pryroda evfemizmiv [Linguistic nature of euphemisms]. Nauk. zhurn. Lviv. derzh. un-tu bezpeky zhyttiediialnosti «Lviv. filol. Chasopys» - Scientific Journal of Lviv State University of Life Safety "Lviv Philological Journal», 5, 70-71. https:// doi.org/10.32447/2663-340X-2019-5-12 [in Ukrainian]. 5. Kosmeda, T. A., \& Khaliman, O. V. (2013). Movna hra v paradyhmi interpretatyvnoi linhvistyky. Hramatyka otsinky. Hramatychna ihrema (teoretychne osmyslennia dyskursyvnoi praktyky) [Language game in the paradigm of interpretive linguistics. Grammar of estimation. Grammar game (theoretical understanding of discursive practice)]. Drohobych: Kolo [in Ukrainian]. 6. Matsko, L. I., 
Sydorenko, O. M., \& Matsko, O. M. (2005). Stylistyka ukrainskoi movy [Stylistics of the Ukrainian language]. Kyiv: Vyshcha shkola [in Ukrainian]. 7. Ozhohan, V. (1997). Zaimennykovi slova u hramatychnii strukturi suchasnoi ukrainskoi movi [Pronoun words in the grammatical structure of the modern Ukrainian language]. Kuiv: NAN Ukrainy. In-t ukr. movy [in Ukrainian]. 8. Poltavets, Iu. (2012). Osnovni pidkhody do vyvchennia evfemizmiv i dysfemizmiv [Basic approaches to the study of euphemisms and dysphemisms]. Humanitarna osvita $v$ tekhnichnykh navchalnykh zakladakh - Humanities education in technical educational institutions, 24, 225-236 [in Ukrainian]. 9. Reshetarova, I. V. (2010). Zasoby evfemii v masmediinomu dyskursi pochatku XX stolittia [Means of euphemia in the mass media discourse of the beginning of the XXI century]. Extended abstract of candidate's thesis. Donetsk: DNU [in Ukrainian]. 10. Khaliman, O. V. (2019). Hramatyka otsinky: morfolohichni katehorii ukrainskoi movy [The Grammar of estimation: morphological categories of the Ukrainian language]. Kharkiv: Maidan [in Ukrainian]. 11. Shkitska, I. Yu. (2011). Zaimennyky «ty» — «Vy» v manipuliatyvnii stratehii pozytyvu [The pronouns «ти» — «Ви» in the manipulative strategy of the positive]. Aktualni problemy slovianskoi filolohii. Ser. «Linhvistyka i literaturoznavstvo» - Actual problems of Slavic philology. Series «Linguistics and Literary Studies», XXIV, 400-408 [in Ukrainian]. 12. Shkitska, I. Iu. (2012). Manipuliatyvna stratehiia pozytyvu $\mathrm{v}$ ukrainskii movi [Manipulative strategy of the positive in the Ukrainian language]. Doctor's thesis. Kyiv: In-t movoznavstva im. O. O. Potebni NAN Ukrainy [in Ukrainian]. 13. Shherbinina, Yu. V. (2004). Russkij yazyk: Rechevaya agressiya i puti ee preodoleniya [Russian language: Speech aggression and ways to overcome it]. Moskva: Flinta: Nauka [in Russian]. 14. Brown, P., \& Levingson, S. (1987). Politeness: Some Universals in Language. Cambridge: Cambridge Univ. Press [in English].

Халіман Оксана Володимирівна - кандидат філологічних наук, доцент кафедри української мови, Харківський національний педагогічний університет імені Г. С. Сковороди; вул. Валентинівська, 2, Харків, 61168, Україна.

Tel.: +38-066-55-903-66

E-mail: khaliman_oksana@ukr.net

https://orcid.org/0000-0001-6952-0627

Khaliman Oksana Volodymyrivna - Ph.D. in Philology, Associate Professor at the Department of Ukrainian Language, H. S. Skovoroda Kharkiv National Pedagogical University; Valentynivska Str., 2, Kharkiv, 61168, Ukraine.

Надійшла до редакції 20 серпня 2020 року

\section{CITATION}

ДСТУ 8302:2015: Халіман О. В. Функціювання морфологічних одиниць як евфемізмів / дисфемізмів в аспекті граматики оцінки. Лінгвістичні дослідження: зб. наук. пр. Харк. нац. пед. ун-ту імені Г. С. Сковороди. Харків, 2020. Вип. 53. С. 155-165. DOI: https://doi.org/10.34142/23127546.2020.53.14

APA: Халіман, О. В. (2020). Функціювання морфологічних одиниць як евфемізмів / дисфемізмів в аспекті граматики оцінки. Лінгвістичні дослідження, 53, 155-165. DOI: https://doi.org/10.34142/23127546.2020.53.14 